\title{
SOME GOGNITIVE BIASES DURING GO-PLAYING OR HOW BEHAVIORAL ECONOMICS COULD TEACH US HOW TO BE BETTER GO PLAYERS
}

\author{
Laura-Augustina AVRAM ${ }^{\text {a* }}$ \\ a) Babeș-Bolyai University, Faculty of Economics and Business Administration, \\ Cluj-Napoca, Romania
}

Please cite this article as:

Article History:

Avram, L.A., 2018. Some cognitive biases during go- Received: 1 September 2018 playing or how behavioral economics could teach us Accepted: 21 November 2018 how to be better go players. Review of Economic Studies and Research Virgil Madgearu, 11(2), pp.33-59.

doi: 10.24193/RVM.2018.11.25.

\begin{abstract}
As human beings, we have cognitive limitations which in diverse contexts and on a regular basis stop us from taking the best decisions. Some of our cognitive biases are caused by our cognitive limitations, some by the fact that we give more importance than necessary to unimportant things (e.g., framing). Acknowledging the existence of biases and using debiasing techniques might be useful for reaching a better understanding of games like Go. For behavioral economists, Go players could be an interesting group to experiment on because of their particular characteristics (see, e.g., Rieger and Wang, 2016).
\end{abstract}

Key words: behavioral economics; game of Go; biases; heuristics JEL Classification: $C 72$; $D 90$

(C) 2018 Alma Mater Publishing House. All rights reserved.

* Corresponding author. E-mail address: laura.avram@econ.ubbcluj.ro. 
Review of Economic Studies and Research Virgil Madgearu, 2018, 11(2)

\section{References:}

1. Abdukadirov, S., 2016. Nudge Theory in Action. Behavioral Design in Policy and Markets. Available at: <https://link-springer-com. ezproxy1.hw.ac.uk/content/pdf/10.1007\%2F978-3-319-31319-1. pdf\%oAhttps://drive.google.com/open?id=oB544TwTVwnWkOHp 3dzdVNjRCYoU> [Accessed 10 September 2018].

2. Anon, 1998. Proverbs. Traditional wisdom for the game of Go. Santa Monica, USA.

3. Ariely, D., Loewenstein, G. and Prelec, D., 2006. Tom Sawyer and the construction of value. Journal of Economic Behavior and Organization, 6o(1), pp.1-10.

4. Avram, L.A., 2016. An interdisciplinary approach to the game of go and a brief presentation of the recent win of Alphago. Review of Economic Studies and Research Virgil Madgearu, 9(1), pp.5-18.

5. Berlekamp, E. and Wolfe, D., 1994. Mathematical Go Endgames: Nightmares for Professional Go Players. The United States of America: Ishi Press International.

6. Bilalić, M., McLeod, P. and Gobet, F., 2010. The mechanism of the einstellung (set) effect: A pervasive source of cognitive bias. Current Directions in Psychological Science, 19(2), pp.111-15.

7. Browne, C., 2008. Automatic generation and evaluation of recombination games. Queensland University of Technology. Available at: <https://eprints.qut.edu.au/17025/1/Cameron_ Browne_Thesis.pdf $>$ [Accessed 10 September 2018].

8. Burmeister,J.M.,2000.Studiesin Human and ComputerGo:Assessing the Game of Go as a Research Domain for Cognitive Science. (October). Available at: <http://www.itee.uq.edu.au/ janetw/Computer Go/ PhD_thesis.pdf\%5Cnhttp://staff.itee.uq.edu.au/janetw/Computer Go/CS-TR-339.html> [Accessed 10 September 2018].

9. Chan, H., 1996. Application of Temporal Difference Learning and Supervised Learning in the Game of Go. Available at: <http:// www.cs.cuhk.hk/ king/PUB/horace_thesis.ps.gz> [Accessed 10 September 2018].

10. Cowley, M.B., 2002. Confirmation Bias as a Default Heuristic in NoviceChessPlayers'ProblemSolving (UndergraduateDissertation). SSRN Electronic Journal, (March). Available at: <https://www.ssrn. com/abstract=2992919> [Accessed 10 September 2018]. 
11. Dhar, R. and Wertenbroch, K., 2000. Consumer Choice Between Hedonic and Utilitarian Goods. Journal of Marketing Research, 37(1), pp.6o-71. https://doi.org/10.1509/jmkr.37.1.60.18718.

12. Halpern, D., 2015. Inside the Nudge Unit. Great Britain: Penguin Books.

13. Johnson, E.J., Häubl, G. and Keinan, A., 2007. Aspects of Endowment: A Query Theory of Value Construction. Journal of Experimental Psychology: Learning Memory and Cognition, 33(3), pp.461-74.

14. Kahneman, D., 2003. Maps of Bounded Rationality: Economicst Psychology for Behavioral. The American Economic Review, 93(5), pp.1449-75.

15. Kahneman, D., 2011. Thinking, Fast and Slow. USA: Farrar, Straus and Giroux.

16. Kahneman, D., Knetsch, J.L.. and Thaler, R.H.., 1990. Experimental Tests of the Endowment Effect and the Coase Theorem Authors. Journal of Political Economy, 98(6), pp.1325-48.

17. Kahneman, D. and Tversky, A., 1973. On the psychology of prediction. Psychological Review, 80(4), pp.237-51.

18. Kahneman, D. and Tversky, A., 1979. Prospect Theory: An Analysis of Decision under Risk. Econometrica: Journal of the Econometric Society, 47(3), pp.263-91.

19. Koulen, M., 1986. Go - Die Mitte des Himmels. Köln, Germany: DuMont Buchverlag Köln.

20. Larrick, L.P., 2004. Debiasing. In: Koehler, D.J. and Harvey, N., ed. 2004. Blackwell Handbook of Judgment and Decision Making, pp.316-38.

21. Miura, Y., 1995. Go. An Asian Paradign For Business Strategy. Tokyo, Japan.

22. Morewedge, C.K., Yoon, H., Scopelliti, I., Symborski, C.W., Korris, J.H., Kassam, K.S., 2015. Debiasing Decisions. Policy Insights from the Behavioral and Brain Sciences, 2(1), pp.129-40. https://doi. org/10.1177/2372732215600886.

23. Phillips, J.K., Klein, G. and Sieck, W.R., 2004. Expertise in Judgment and Decision Making: A Case for Training Intuitive Decision Skills. In: Koehler, D.J. \& Harvey, N., ed. 2004. Blackwell Handbook of Judgment and Decision Making, pp.297-315.

24. Rieger, M.O. \& Wang, M., 2016. Cognitive Skills and Competence in Go. [unpublished conference article] (Personal communication, 22 July 2016). 
Review of Economic Studies and Research Virgil Madgearu, 2018, 11(2)

25. Schmidt, R., 1981. Das spielt das Volk in China, Frankfurt am Main. Germany: China Studien- und Verlagsgesellschaft.

26. Sherman, J., Gawronski, B. and Trope, Y., 2014. In two minds. DualProcess Theories of the Social Mind. New York: The Guilford Press.

27. Simon, H.A., 1955. A Behavioral Model of Rational Choice. The Quarterly Journal of Economics, 69(1), pp.99-118.

28. Simon, H.A., 1956. Rational choice and the structure of the environment. Psychological Review, 63(2), pp.129-38.

29. Simon, H.A. and Chase, W.G., 1973. Skill in Chess. American Scientist, 61(4), pp.394-403.

30. Stanovich, K.E. and West, R.F., 2000. Individual differences in reasoning: implications for the rationality debate? Behavioral and Brain Sciences, 23(5), pp.645-726.

31. Thaler, R.H., 1988. Anomalies: The Winner's Curse. Journal of Economic Perspectives, 2(1), pp.191-202.

32. Thaler, R.H., 1994. Quasi Rational Economics. Available at: <https://books.google.com/books?hl=en\&lr=\&id=BgGs1Lx3oDEC \&pgis $=1>$ [Accessed 10 September 2018].

33. Thaler, R.H., 1980. Toward a positive theory of consumer choice. Journal of Economic Behavior \& Organization, 1, pp.39-6o.

34. Thaler, R.H. and Sunstein, C.R., 2008. Nudge. New Haven \& London: Yale University Press New.

35. Tversky, A. and Kahneman, D., 1973. Availability: A heuristic for judging frequency and probability. Cognitive Psychology, 5(2), pp.207-32.

36. Tversky, A. and Kahneman, D., 1974. Judgment under Uncertainty: Heuristics and Biases. Science, 185(4157), pp.1124-31.

37. Tversky, A. and Kahneman, D., 1986. Rational Choice and the Framing of Decisions. The Journal of Business, 59(4), pp.251-78.

38. Tversky, A. and Kahneman, D., 1981. The framing of decisions and the psychology of choice. Science, 211(4481), pp.453-58.

39. ***, The AlphaGo Games, 2017. AlphaGo Website. [online] Available at: <http://www.alphago-games.com/> [Accessed 10 September 2018].

40. ${ }^{* * *}$, Go kifu. [online] Available at: <http://gokifu.com/> [Accessed 10 September 2018]. 